\title{
Civil Society in Albania as an Important Tool of Democracy: A Literature Review
}

\author{
Ermelinda Shehaj \\ Phd. Candidate, Institute of European Studies, University of Tirana, Albania \\ Email: ermelindashehaj@yahoo.com \\ Elona Krashi \\ PhD Candidate, Faculty of Social Sciences, University of Tirana, Albania \\ Email: ekrashi@gmail.com \\ Anila Gjonaj \\ Faculty of Social Sciences, University of Tirana, Albania \\ Email: anilagjonaj@yahoo.com
}

Doi:10.5901/ajis.2016.v5n3s1p430

\begin{abstract}
Albania has been the most isolated country of Eastern Europe during the communist era. Today is trying to close the successful process of democratization and integration in the European Union. One of the main prerequisites for achieving this goal is the strengthening of civil society. The development of civil society is one of the biggest challenges of the Albanian society of 10-year-old recently. Although the presence of civil society is a new experience, it is now accepted that partnership and the essential role it plays in the process of developing democracy and society education. A healthy civil society through its products guarantees a stable democracy. This is made possible by the role it plays in the development process. Standing between the individual, the state and the market, civil society mitigates negative trends, creates social capital, carries develops new values and traditions. NGOs, media and other non-state institutions are essential elements of democracy. My work analyzes and describes theoretical civil society as a new phenomenon in Albania. Democratization in our country has not been successfully because Civil Society has been weak; it does not serve as a real pressure over the policy and decision makers. This paper, also tries to provide a concise overview of the Civil Society in Albania and the culture of democracy. Civil Society is a very important element for human rights. We will conclude and found that Civil Society also determines the level of democracy in a country. A country has a consolidated and real democracy when it has a strength Civil Society that plays an important role as an "eye watching" over the political parties and especially the governance.
\end{abstract}

Keywords: Civil Society, Democratization, Political parties, Governance, Human Rights

\section{Introduction}

After the fall of communism, Albania is trying to successfully complete the process of democratization and integration in the European Union. Besides the acquisition of democratic values one of the prerequisites for achieving this goal is the strengthening of civil society. Nowadays, the Albanian society is evidenced in the role and importance of civil society as an important component of the instrument or the democratization of society. Construction of civil society has already become a common ideal, especially for the countries of the East, where its existence is presented as a necessity or an immediate need to help the process of democratization.

In reality the concept of civil society in Albanian society is relatively new. This relates to the past of our country, which ruled the communist regime. Obviously the presence of this system does not allow and do not conceive the existence of civil society. Civil society regarded as a foreign body which not only protected individuals, but alienate them. For individuals the state was the latter who knew what was best for them. Civil society in communist regimes was closely related to the Marxist-Leninist ideology and identified as foreign individuals, which were completely contrary to their interests.

Albania has started to talk and discuss the role and importance of civil society. This is because civil society is an important instrument in the process of European integration and the building of a system of genuine democratic predominantly democratic values, balancing and control of powers, the independence of their government limited, and 
mechanisms of the state of right and legal.

In this context, the importance of the civil society to society is substantial. Therefore, I have tried, in a modest way to present it simple and understandable history of civil society in Albania, its role in solving the problems of its features, impacts its positive, its relations with the state, politics, citizen as well as its challenges in the future. This paper aim to explain why civil society as a concept, the phenomenon is worth immediate priority to building a democratic society, political considerations, economic and historical that have led to the construction of civil society in Western Europe and not those East .

Recently, civil society has begun to take a special significance. This can be seen in many aspects such as its commitment as a counterweight to the politics and the state. It is playing more and more an important role in engaging citizens to assert their rights and to remind the government, political elites, not to forget their mission, that of building a democratic right and clean and above all the rule of law and respect. Philosopher and political scientist, German Erhard Epler in his book "Return of Policy" writes: "For Tocqueville freedom of Americans was not guaranteed by the fact that the president elected by the citizens, but the willingness and their ability to get themselves down issues that pertained". This phenomenon has apparently begun to emerge in our country, of course we are very far from the American model that describes Tocqueville it for many different reasons, such as are political, economic, social-cultural one. Albania has much to do to achieve a democratic system in all aspects of social life. We are facing changes in our lives, because the transition from a closed to an open society requires its time and above all, a hierarchy of values internalized in the individual. This rapid changeover apparently has caused great confusion in our society, which is facing completely different values from the ones that appeared in the previous regime. The state is no longer the individual who decides, but the latter thanks to which the state functions and fulfills its mission to serve the public interest.

Governments in post- communist countries are obliged to under the laws and principles of democracy and the market economy to build a civil society with differences and social interests of distinctive papers based on the values and merits of the individual, equality of chances and opportunities and not on equality economic opportunities as it had happened in communist system.

Did it happen in Albania this phenomenon, the gaining of merit and equal opportunities for all? Naturally, I do not think. The reasons why I think in this way are numerous; one of the most important is the lack of values and democratic culture and the lack of a genuine democratic experience. The Albanian society, as well as other Eastern countries, faced with numerous paradoxes and conflicts as conflicts between the political system and the interests of society, the conflict between goals and means as well as conflict of values. In many cases, the political culture of these countries, as well as our country is filled with paradoxes as the political class which came to power to fight communism, apparently has forgotten that promise and is using the method itself to recall system previous, which lacked different opinion, compromise the existence of fundamental rights and freedoms of the individual. There is no way to be different, because we inherit from the past tradition of political culture lukewarm. Situated in such conditions, a company must have at present civil society as the voice of protecting the citizens, to remind the political elites, government and state government in accordance with democratic principles while respecting the laws of the state. I think that this aspiration is a bit remote, as we have stressed on the need and necessity to have a democratic system without knowing what it really means this system, what were the criteria's, values that we should learn before to reach this system.

When people fully supported the democratic system, they forgot that a democracy needs a democratic culture. Its absence made our society to experience a real apocalypse on the enjoyment of human rights and their fair distribution. These interests were instead aimed at building democracy actually targeted private gains, rapid enrichment without relying on individual values. I think this phenomenon is best embodies statement Rene Levaser de La Sarte: "We dreamed about Wonderland and now we are back to earth in this reality; and those with whom we shared our miracle, now have abandoned us" (Vajdenfeld: 1999). And it happened in the Albanian context since there was a misinterpretation of the enjoyment of fundamental rights. Freedom has created the idea that everybody can snatch everything, and could steal without worrying about whether it is his property or belongs to all Albanians. "The state had never spoken individual, Albanian citizen that it was created to defend it from aggression by others, but rather the state always has been imposed on the individual as a gendarme command, as an absolute power that has used force to guaranteed through social fear transmission status and subordination that always requires the service of the terrible tyranny " (Ngjela: 2006). This situation also revealed a new phenomenon for our country, that the transition from one-party to multi-party pluralist it. The large number of parties, the diversity of programs and alternatives to their policy led to what Weber has defined as a shift from the ethics of obedience, that of taking responsibility of the latter to be an extremely difficult task (Vajdenfeld:1999).

In such conditions the Albanian society was faced with numerous differences, conflicts and paradoxes. The political elite were and continue to be very far from the ideals of the people, his aspirations to establish a democratic 
system. The policy arena consists of politicians who live by politics and not for politics. They apparently have not yet been able to show us clear and convincing evidence of the policy change from the past, but are able to transmit shortages of democratic values and principles. When these principles were missing to them what can we expect from them to respect, which is the example that they transmit citizens?

At this moment I think that civil society has an indispensable role to tell the politicians, the government and state that it together with the citizens and their commitment, are always ready to act and to protest peacefully. Civil society is the society that we need above all, that protects us from arbitrary power and its abuse. Of course, it cannot arise from nowhere; it requires courageous people, educated, tolerant to know how to cope with problems, giving a solution. Building civil society should be our common calling. Its construction is a condition for the existence of a democratic system.

\section{Literature Review}

There are many different theories and concepts for civil society. Since the time of Aristotle, Plato and Cicero "civil society" was explained as a whole, unified state and political society. Between the two concepts, now recognized as separate from political science and sociology, there was no separation barrier (Krasniqi: 2004). As for the origins of the concept, we can say that until the 18th century the term "civil society" was the same with the state or with political society. Locke spoke of civil government which was an alternative term with the term civil society or political.

"According to Locke's political and civil society exists only when a number of people are together in society by giving up any right executive of natural law and the public footing. This is achieved when a number of people, in the natural state, enter into society to create a nation, a political body under a central government or otherwise, when a person joins and is included in a government already established" (Stumpf: 2006).

Civil society was named and established as a concept in the debates of the 18th century on despotism. In this period there have been a number of definitions about the concept of civil society. Civil society is an important and essential element of Western civilization and the basis of a society that "sets the space of freedom, between governments and citizens" (Epler: 2001).

Tocqueville highlighted various forms of civic organization which was an important factor to realize those tasks that citizens would not be able to realize the dot if they were separated. This form of organization was called "vibrant democracy" (Tushi: 2007). He writes that Americans of every age and social class, every religion is continuously collected together. They have not only business and trade associations. He failed to do what was it processed Tocqueville conceptual divide between state and society, unlike the thought of Marx, and so presented a third space. Tocqueville identified three action areas of society.

According Tocqueville political society is nothing but art, community, organization and groups in society. In civilized societies there are political organizations as local government bodies, political parties and public opinion. There are civil or civic organizations, churches, schools, literary or scientific societies, trade organizations and the press. Vitality, the life of these organizations, immense strength and power through which they contribute to the body politic, political space represents what Tocqueville qualifies as political society. Political society controlled by centralized government excesses, particularly in democratic societies. Political society as it considers constitutes the Tocqueville "independent eye of society" that monitors public life.

Another philosopher who has contributed to the definition of civil society is Hegel. According to him the individual comes from the family which has a universal character as relations between families members are based on feelings of love being stripped of any interest (Stumpf: 2006). Individuals already in plan put their interests first. By Hegel civil society is nothing but relations have individuals with different vested interests. For Hegel in the development of human relations which have a universal dialectic which opposes represented by the particular family which is represented by the individual himself. The family, in this analysis, serves to show us the universal incarnation, while civil society represents the individual who sets his goals, regardless of other family members.

Tocqueville praised civil society as a "school of democracy" (Krasniqi: 2004), which works through associations and social organizations, while the German philosopher Jurgen Habermas formulated a new concept. He sees civil society as the third area along the state and the market, which is characterized by public articulation of societal problems. Habermas considers communicative power and solidarity as the most important resources of this company, with which it conducts criticism and makes corrections policy. Civil society is: composed of unions, associations, groups, organizations and movements diversified created spontaneously, "who find, recognize and breed all the problems of society in relation to privacy and then spread loud in political society. "So, for Habermas essence of civil society lies in 
the organization and existence of active associations and unions other than built on a voluntary basis, non-state and nonprofit, which with their activity define structures communication to the public on all components of social life.

The term of civil society refers to a set of voluntary organizations and social institutions which form the basis for a functioning society. According to Centre for Civil Society at London School of Economics this term shall refer to the scope of free collective action, not mandatory, some interests, common goals and values. Civil societies are so different from the spaces, actors and institutional forms, and the degree of autonomy.

After identifying the main theories about civil society and its theoretical concepts, what we can say it is that there is a direct link between civil society and political system. This is a duo that determines the development of society. The existence of a civil society consolidated emancipated is obviously a necessary condition to have a democratic system proper, where institutions are stable, the law is respected and implemented, citizens are engaged in public affairs and the struggle to protect rights them through their active participation in various organizations and associations.

\section{Methodology}

This work like any other work in the field of political science is based on the necessary information that will serve to realize its objectives. It is important that this information have truthfully. To provide the necessary information for this paper is used method of studying literature and documentation. Use of literature is an unparalleled source. In this literature they are mainly involved civil society theories, concepts and features of its impacts on its negative and positive. Since this study was an analytical approach is based on a detailed analysis of the concepts. The theoretical framework is complete, because it is supported in lectures held during the study period.

\section{Challenges of Civil Society in Albania}

Albanian society has the necessary detachment from extreme politicization and building an active civil society, and stable representative. With the development of civil society are linked reforms, the establishment of the rule of law and justice as well as entry into the big European family. International experience determines that the construction and strengthening of civil society is achieved through the close cooperation of the state and the individual market.

The process of strengthening civil society is important not seen in isolation from the overall development of society. American analyst Christopher Corpora proposes that "the democratic process in Albania to start from the bottom up and not the opposite". He writes "The democratic process so far has developed top-down". The construction of active and effective civil society is associated with many factors. One of the most important is the free initiative of the individual. Only citizens who look beyond the problems of themselves and are capable of supporting civil society in action and undertake initiatives with their citizens and civil society institutions play an important role in the consolidation of the values of a democratic society. "Democracy is based on the conviction that ordinary people extraordinary opportunities exist" (Fozdik: 2010). Citizens not only have the responsibility to solve the problems that concern them, but think about giving answers to problems that cross the border they are personal and concerns the entire society. In this context, civil society represents not only the interests of citizens and not only acts as a mediator between citizens and the state, but it supervises and controls the operational capabilities of the state.

Western experience shows that the prerequisite and basis for successful cooperation between the state, market and civil society is clear division of responsibilities and tasks. The state has a monopoly and the right to draft the adoption of laws, market economy and civil society develops helps spokeswoman governance and underrepresented interests of citizens. Civil society has necessitated the creation of a public asset that is able to criticize and monitor the process of decision making of the government.

Citizen movements of civil society should maintain coherence to be useful to society. Albanian experience shows cases where civic movements and civil society initiatives have not always bring positive developments. '97 Events showed how the protests increase as a result of political discontent balances conducted social decay, destroying the image of the state, damage to institutions and "legitimacy" of violence in the political culture. Of course, the main responsibility for this situation belongs to politicians but also civil society failed to recognize the difference between civilian movement and its misuse. Civil society did not find the strength to react and to propose a way out. NGOs ' 97 failed to devise a strategy to serve as a deterrent and control of government policy at the time. They were simply spectators and reflected only after the outbreak of the crisis highlighting their views against violence and proestablishment of constitutional order. It came so late that it was symbolic impact. '97 Events prove the best idea of an American analyst, Corpora that "the process of democratization and strengthening of civil society should start from the 
lowest levels" (Krasniqi: 2004).

Creating consensus and democratic culture is another real challenge to the future of civil society. Rule of law, economic empowerment and involvement of the country in the process of democratization is linked with possession of a genuine democratic culture where the parties are able to respect each other. Without collaborative and respectful political rights will not be possible to create a new political culture of citizens. The democratic process is difficult and a long road. A real democracy requires not only political reforms and economic success but also creating a new civic mentality in which civil society has an important role.

The first step is the return of confidence to the citizens through the implementation of the election free and fair. Electoral competition must be fair, the votes must be counted as the parties should recognize and respect the outcome of elections. Society and citizens would feel represented and the voice of civil society will have more weight if this obstacle resolved.

Another condition to build a civil society is the belief of the citizen's action. Political elites have questioned the morality and political confidence due to political disappointments. "In the current political class, they are with her finger personalities, people who live for politics and not living politics. Living in politics means being integrally melted and important part of its public development means not to be named, vegetable but contributors " (Tushi: 2005). Albania still lacks democratic values and norms in the political class. It appears emancipated class, which sometimes reflects the communist political manners of behavior, it's because they are an integral part of the mentality of the Albanian society, a society which is not cultivated by democratic rules and principles.

The lack of a genuine democratic experience, such a culture makes the steps of moving towards a democratic system be awkward. What should be the motivation of our country's development is the realization of the elections free and fair elections, respect for the law and thought differently as: Democracy is but maturity and being a responsible person for the whole society who understands well and do his best for the territory where he lives.

\section{Conclusions}

Civil society is the most important tool that serves to strengthen freedom and democracy for the citizens of Albania. It is the social instrument that enables resolution of the struggle between inclusion and exclusion of the citizen as a man of complete integrity and social policy in political and public life. It is clear that without an active civil society, consolidated, modern civilization does not competitive. Civil society offers us a single civic identity, which belongs not to the state or private consumers but citizens. This rejoins society of rights and responsibilities together and allows us to take control of our governments and markets. Civil society has become a factor that is expanding space of citizen service. Citizen living in such a society, organized and structured does not expect anything to solve the state. Citizens of a consolidated civil society are people who are capable of solving their own problems. Rights and duties are the foundations of citizenship. Here is the strength of civil society which strikes a balance between rights and duties. It is the forerunner of democracy. Democracy does not work without it, is simply a system like the others, as long as there is space to develop thought and civic organization.

Albania's level of development of civil society is inevitably linked with the level of social development in general. Our country is still in the early stages of the democratic system and therefore civil society is fragile, inexperienced and unconsolidated. During the transition period carried away from its communist past problems are a real obstacle to the development of society and the system.

In my opinion the correct idea is that everything should start with the strengthening of civil society, creating a space where citizens feel themselves decision makers, be they actors. Despite the achievements that has made civil society in Albania it is still in its infancy; its role remains modest solving important problems of national policy. This relates not only to its immaturity but with all sectors of our society, who apparently will require a long time to learn and implement genuine democratic values.

The role of civil society is to produce ideas. We need ideas and not a political revolution and this is achieved by civil society. It requires civic engagement. Undoubtedly we need to look beyond ourselves, our threshold. Only in this way we will achieve are a civilized, free and responsible.

The process of European integration cannot possibly be successful without the participation of other social actors. The involvement and commitment of other social actors in the integration process is an indispensable need for the success of the process itself. And practically it would be an instrument to fight apathy, lack of participation, and will really help in the growth and strengthening of civil society, strengthening of democracy. The democratic system itself cannot be successful without a civil society that takes part, which responds to the phenomena and contribute to the development of 
the country.

Finally, it concluded that civic engagement, the ability of self-organization, mobilization and volunteerism are still minimal, the willingness of citizens to the recognition and enforcement has moved slowly, and the participation of civil society institutions in correcting and formulating policy decision remain weak. Civil society in Albania has failed to make the progress necessary before the development of political society. It reflected its weakness; it is identified with political society and in any case has left behind her. This is due to the fact that the Albanian civil society operates and develops in a country where the state and its institutions are still tentative.

\section{References}

Epler, E. (2001). Rikthimi i Politikës (The return of Policy), Tiranë: ISPS \& Rinia

Krasniqi, A. (2004). Shoqëria Civile në Shqipëri (Civil Society in Albania), Tiranë: GEER

Mayer, L. (2003). Politikat krahasuese (Comparative politics), Tiranë: ORA

Ngjela, S. (2006). Reformë Shqiptare (Albanian Reform), Tiranë: Shtypshkronja MNS

Tocqueville, A. (2002). Demokracia në Amerikë (Democracy in America), Tiranë: Fondacioni Soros \& Kristalina-KH

Tushi, G. (2006). Politika dhe Qytetari (Politic and citizen), Tiranë: EMAL

Tushi, G. (2007). Shoqëria Civile (Civil Society), Tiranë: Dudaj

Vajdenfeld, V. (1999) Demokracia dhe Ekonomia e Tregut në Europën Lindore (Democracy and Trade Economy in Eastern Europe), Tiranë: Shtëpia e Librit dhe e Fondacionit Soros 